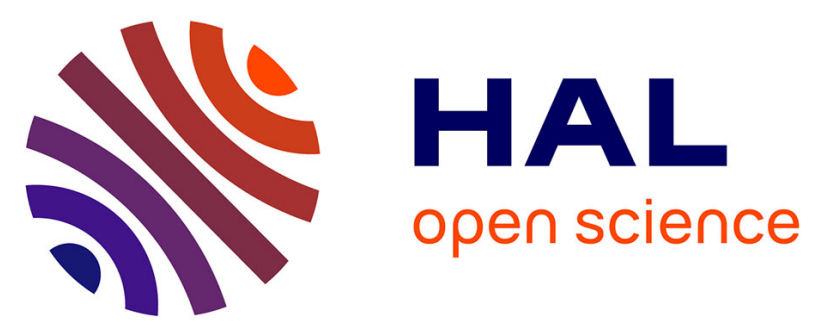

\title{
Source apportionment of PM2.5 organic aerosol over Europe: Primary/secondary, natural/anthropogenic, and fossil/biogenic origin
}

András Gelencsér, Barbara May, David A. Simpson, Asunción Sánchez-Ochoa, Anne Kasper-Giebl, Hans Puxbaum, Alexandre Caseiro, Casimiro Pio, Michel Legrand

\section{To cite this version:}

András Gelencsér, Barbara May, David A. Simpson, Asunción Sánchez-Ochoa, Anne Kasper-Giebl, et al.. Source apportionment of PM2.5 organic aerosol over Europe: Primary/secondary, natural/anthropogenic, and fossil/biogenic origin. Journal of Geophysical Research: Atmospheres, 2007, 112 (D23S04), 1 à 12 p. 10.1029/2006JD008094 . insu-00376309

\section{HAL Id: insu-00376309 \\ https://hal-insu.archives-ouvertes.fr/insu-00376309}

Submitted on 11 Mar 2021

HAL is a multi-disciplinary open access archive for the deposit and dissemination of scientific research documents, whether they are published or not. The documents may come from teaching and research institutions in France or abroad, or from public or private research centers.
L'archive ouverte pluridisciplinaire HAL, est destinée au dépôt et à la diffusion de documents scientifiques de niveau recherche, publiés ou non, émanant des établissements d'enseignement et de recherche français ou étrangers, des laboratoires publics ou privés. 


\title{
Source apportionment of PM2.5 organic aerosol over Europe: Primary/secondary, natural/anthropogenic, and fossil/biogenic origin
}

\author{
András Gelencsér, ${ }^{1}$ Barbara May, ${ }^{2}$ David Simpson, ${ }^{3,4}$ Asunción Sánchez-Ochoa, ${ }^{5}$ \\ Anne Kasper-Giebl, ${ }^{5}$ Hans Puxbaum, ${ }^{5}$ Alexandre Caseiro, ${ }^{6}$ Casimiro Pio, ${ }^{6}$ \\ and Michel Legrand ${ }^{7}$
}

Received 2 October 2006; revised 12 February 2007; accepted 6 April 2007; published 7 September 2007.

[1] On the basis of a 2-year comprehensive data set obtained within the CARBOSOL project, seasonal source apportionment of PM2.5 aerosol is attempted for five rural/remote sites in Europe. The approach developed combines radiocarbon measurements with bulk measurements of organic carbon (OC), elemental carbon (EC), and two organic tracers (levoglucosan and cellulose). Source types are lumped into primary emissions from fossil fuel combustion and biomass burning, bioaerosol, and secondary organic aerosol from precursors emitted by fossil and nonfossil sources. Bulk concentration ratios reported for these source types in the literature are used to estimate the source contributions which are constrained by measured radiocarbon concentrations. It has been found that while fossil-related sources predominate EC throughout the year at all sites, the sources of OC are primarily biogenic and markedly different between summer and winter. In winter biomass burning primary emission is the main source, with sizable additional contribution from fossil fuel combustion. In contrast, in summer secondary organic aerosol (SOA) from nonfossil sources becomes predominant (63-76\% of TC), with some contribution of SOA from fossil fuel combustion. The results agree well with recent findings of other authors who established the predominance of biogenic SOA for rural sites in summer in Europe. An uncertainty analysis has been conducted, which shows that the main conclusions from this study are robust.

Citation: Gelencsér, A., B. May, D. Simpson, A. Sánchez-Ochoa, A. Kasper-Giebl, H. Puxbaum, A. Caseiro, C. Pio, and M. Legrand (2007), Source apportionment of PM2.5 organic aerosol over Europe: Primary/secondary, natural/anthropogenic, and fossil/biogenic origin, J. Geophys. Res., 112, D23S04, doi:10.1029/2006JD008094.

\section{Introduction}

[2] Although it has been recognized that organic aerosol plays an increasingly important role in inadvertent climate modification, their origin in the boundary layer as well as in the free troposphere is virtually unknown. Current models can simulate the global distribution of bulk organic aerosol

\footnotetext{
${ }^{1}$ Air Chemistry Group of the Hungarian Academy of Sciences, Department of Earth and Environmental Sciences, University of Pannonia, Veszprém, Hungary.

${ }^{2}$ Insitute für Umweltphysik, University of Heidelberg, Heidelberg, Germany.

${ }^{3}$ Cooperative Programme for Monitoring and Evaluation of the LongRange Transmission of Air Pollutants in Europe, Meteorological Synthesizing Centre-West, Norwegian Meteorological Institute, Oslo, Norway.

${ }^{4}$ Also at Department of Radio and Space Science, Chalmers University of Technology, Gothenburg, Sweden.

${ }^{5}$ Institute for Chemical Technologies and Analytics, Vienna University of Technology, Vienna, Austria.

${ }^{6}$ Departamento de Ambiente e Ordenamento, Universidade de Aveiro, Aveiro, Portugal.

${ }^{7}$ Laboratoire de Glaciologie et Géophysique de l'Environnement, Centre National de la Recherche Scientifique, Saint Martin d'Hères, France.

Copyright 2007 by the American Geophysical Union. 0148-0227/07/2006JD008094
}

by considering all major types of organic aerosol, including primary organic aerosol emitted by fossil fuel combustion, biomass burning and vegetation, as well as secondary organic aerosol (SOA) formed by the photo-oxidation of anthropogenic and natural volatile organic compounds (VOCs) [Liousse et al., 1996; Chung and Seinfeld, 2002]. At the level of our current understanding (see Gelencsér [2004], and Kanakidou et al. [2005] for reviews) these models can only estimate atmospheric concentrations of organic aerosol with very high uncertainties, and the accurate apportionment of the anthropogenic contribution is beyond their capabilities. That prevents us from predicting how future changes in human activities will affect the global distribution and properties of organic aerosol and thus how they will modify global climate.

[3] In terms of source apportionment the simple question would be to know what fraction of organic aerosol results from anthropogenic and natural sources, but this is a question to which no definite answer could ever be hoped for. The reason for this is that the theoretical borderline between these two source types simply dissolves when secondary aerosol formation processes are considered. The amount of aerosol produced from a given source depends in a nonlinear way upon the presence of other aerosol species, 
and on atmospheric oxidation processes. Therefore new questions have to be asked which would help improve our understanding on the key processes involved in organic aerosol production. The first is what fraction of $\mathrm{OC}$ is primary and secondary in origin. While this question is straightforward for individual particles (e.g., bioaerosol particles), it becomes vague when semivolatile organic species are considered which could either be emitted directly or formed in photochemical reactions (e.g., short-chain dicarboxylic acids). Apart from these conceptual ambiguities only indirect methods are available to answer this question, and only on a regional scale. Another key question is what fraction of $\mathrm{OC}$ comes from fossil and biogenic sources, a more definitive question for which up-to-date radiocarbon measurements can provide direct answers. In policy terms, the question which we would like to answer is to what extent we can reduce atmospheric concentrations of aerosols through reduction of anthropogenic emissions.

[4] In the field of aerosol chemistry, measurement of the ${ }^{14} \mathrm{C}$, which is produced naturally in the atmosphere, can be used for basic apportionment of modern and fossil fuel carbon. Apart from the experimental difficulties and the related uncertainties, this simple division alone cannot provide apportionment of natural and anthropogenic sources since modern carbon could result from natural emissions as well as biomass burning or other anthropogenic activities (e.g., cooking). ${ }^{14} \mathrm{C}$ measurements made on fine particles collected at an urban/suburban site and a forested rural site revealed that the contribution of modern carbon varied between $27-73 \%$ and $44-77 \%$, respectively [Lemire et al., 2002]. Similarly, in urban aerosol in Zürich in August 2002 the share of contemporary carbon was found to vary between 51 and $80 \%$ [Szidat et al., 2004]. Since these measurements were performed on aerosol in the Northern Hemisphere, one would expect biogenic sources to be even more important on a global scale.

[5] Primary organic aerosol emission can be reliably constrained in source apportionment studies based on source emission estimates and measured ambient concentrations of atmospheric tracers only for areas under strong anthropogenic influence, such as the South Californian Air Basin. These studies could either be based on sourceoriented models which use emission data and transport calculations to predict concentrations at specific receptor sites, or on receptor-oriented models which infer source contributions by calculating the best fit linear combination of emission source chemical profiles of atmospheric tracer compounds. On this basis SOA can be derived as the residual amount left after apportionment of primary sources. On the other hand, source apportionment data based on organic tracers in rural and remote locations remain sparse.

[6] The lack of direct chemical analysis method for the determination of either primary or secondary organic aerosol led to the development of different indirect approaches, among which the most widespread is the method based on variations of measured OC/EC ratios. In this concept elemental carbon (EC) is assumed to be a conservative tracer for primary combustion-generated OC emissions, and SOA simply appears as an increase in the $\mathrm{OC} / \mathrm{EC}$ ratio relative to that of the primary $\mathrm{OC} / \mathrm{EC}$ ratio, particularly during the summer season, showing an increasing trend as the pollution plume moves with the prevailing wind [Turpin and Huntzicker, 1991]. A critical step of this method is the estimation of a characteristic primary $\mathrm{OC} / \mathrm{EC}$ ratio which is usually determined in source areas at times when minimum photochemical activity is expected.

[7] On a global scale, models suggest that direct emission from combustion processes dominates the carbonaceous aerosol sources, amounting to $44.6 \mathrm{Tg} \mathrm{yr}^{-1}$ and $28.5 \mathrm{Tg} \mathrm{yr}^{-1}$ from tropical biomass burning and fossil fuel combustion, respectively [Liousse et al., 1996; Penner et al., 2001]. In contrast, production of secondary organic aerosol (SOA) from photo-oxidation of terpenes is now expected to make up only 13-24 $\mathrm{TgC}_{\mathrm{yr}}^{-1}$ globally [Griffin et al., 1999] (adopted by IPCC [see Penner et al., 2001]). Another recent modeling study has found very low zonally averaged mass contribution of SOA over the entire boundary layer, and somewhat higher, but still relatively small contributions toward the upper troposphere [Chung and Seinfeld, 2002]. The predicted global SOA production was only 11.2 $\mathrm{Tg} \mathrm{yr}^{-1}$, which was in fact lower than the low bound of previous model predictions. While the reasonable agreement between the model-predicted OC mass concentrations and the scarce but available atmospheric observations could give us the false illusion that we have understood the major sources and key processes of organic aerosol properly, mounting evidence suggests that this is far from being the case [Volkamer et al., 2006]. Formerly Andreae and Crutzen [1997] estimated global SOA formation to be in the order of 30-270 $\mathrm{Tg} \mathrm{yr}^{-1}$, comparable to that of secondary sulfate aerosol. In another global model Kanakidou et al. [2000] found that SOA from the ozonolysis of biogenic VOCs contributed about 40-60\% to the total organic aerosol in the tropics and continental regions at northern midlatitudes, and calculated a global SOA production rate of $61-79 \mathrm{Tg}^{-1}$. It should be noted that the model suggested that $\sim 75 \%$ of current biogenic SOA production may be induced by human activities. On a European scale, various studies have suggested that SOA from biogenic emissions should dominate over OC from anthropogenic sources [Andersson-Sköld and Simpson, 2001; Schell et al., 2001; Kanakidou et al., 2005], but the results are very dependent upon model assumptions [AnderssonSköld and Simpson, 2001; Tsigaridis and Kanakidou, 2003]. Further, the increasing evidence of multiphase formation mechanisms [e.g., Gelencsér, 2004; Jang et al., 2002; Kalberer et al., 2004; Limbeck et al., 2003; Simpson et al., 2007] for organic aerosol would invalidate essentially all approaches tried in European or global modeling studies to date, since these models all rely upon gas/particle partitioning theories which assume no further reactions of species once condensed into aerosols.

[8] The substantial differences between the results produced by state-of-the-art European and global models, and the growing evidence of multiple pathways to OC formation point to the urgent need to reconcile atmospheric models with field observations not only with respect to mass concentrations of organic carbon, but also to the distribution of derived parameters such as the relative contribution of SOA. This would necessitate extensive and reliable source apportionment studies in areas outside the immediate source regions.

[9] This paper is the first attempt to provide a first-order source apportionment of organic aerosol along the basic source types considered by atmospheric models, based on a 
comprehensive 2-year data set obtained for PM2.5 aerosol collected at 5 sites in Europe within the EU project CARBOSOL. The approach taken quantitatively combines up-to-date radiocarbon measurements with bulk OC/BC determinations and analyses of specific organic tracers in order to assess the relative contributions of fossil fuel combustion, biomass burning, and natural primary emissions as well as nonfossil and fossil-derived SOA. The results, together with all uncertainties are evaluated by sites and seasons and compared with those of other studies, either modeling or experimental.

\section{Experimental Section and Description of the Approach}

[10] PM2.5 aerosol samples were collected at 6 sites along a west-east transect in Europe between October 2002 and July 2004, on a weekly basis. The sites were: Azores (AZO) (Portugal, $38^{\circ} 38^{\prime} \mathrm{N}, 27^{\circ} 02^{\prime} \mathrm{W}, 50 \mathrm{~m}$ a.s.1.), Aveiro (AVE) (Portugal, $40^{\circ} 34^{\prime} \mathrm{N}, 8^{\circ} 38^{\prime} \mathrm{W}, 40 \mathrm{~m}$ a.s.1.), Puy de Dôme (PDD) (central France, $45^{\circ} 46^{\prime} \mathrm{N}, 2^{\circ} 57^{\prime} \mathrm{E}$, $1450 \mathrm{~m}$ a.s.1.), Schauinsland (SIL) (southwestern Germany, $47^{\circ} 55^{\prime} \mathrm{N}, 07^{\circ} 54^{\prime} \mathrm{E}, 1205 \mathrm{~m}$ a.s.1.), Sonnblick (SBO) (Austrian Alps, $47^{\circ} 03^{\prime} \mathrm{N}, 12^{\circ} 57^{\prime} \mathrm{E}, 3106 \mathrm{~m}$ a.s.l.) and K-Puszta (KPZ) (Hungary, $46^{\circ} 58^{\prime} \mathrm{N}, 19^{\circ} 35^{\prime} \mathrm{E}, 136 \mathrm{~m}$ a.s.1.).

[11] The samples were collected on quartz fiber filters, and stored in the refrigerator until analysis. The detailed description of the sampling sites, sampling and analyses can be found elsewhere [Pio et al., 2007]. Analyses were carried out by one assigned laboratory using a single and validated method from parts of the filters which were distributed according to a predetermined protocol. Radiocarbon determinations were performed on 20 subsets of pooled aerosol samples which were selected to be representative of sites and seasons after the completion of all other analytical measurements, including analysis of radioactive tracers for continental transport processes $\left({ }^{210} \mathrm{~Pb}\right)$. The targets prepared from the filters were analyzed by ${ }^{14} \mathrm{C}$ accelerator mass spectrometry at the accelerator facility of the University of Vienna. The sample preparation involved the combustion of the filters at high temperature $\left(900^{\circ} \mathrm{C}\right.$ for $\left.15 \mathrm{~min}\right)$ together with $\mathrm{Ag}$ wool in a stream of synthetic air $(7.5 \mathrm{ml} / \mathrm{min})$ or pure oxygen $(6.9 \mathrm{ml} / \mathrm{min})$ respectively. All carbon was converted to $\mathrm{CO}_{2}$, which was then reduced by $\mathrm{H}_{2}$ gas to carbon monoxide and further reduced over Fe powder to graphitic carbon at $610^{\circ} \mathrm{C}$. The ${ }^{14} \mathrm{C}$ results were reported as percentage of modern carbon $(\mathrm{pmC})$ relative to oxalic acid used for radiocarbon dating (SRM4990b) [Steier et al., 2006]. The rationale behind the selection of samples as well as all details of sample preparation, analysis, and use of correction methods for proper interpretation of data are reported by B. May et al. (manuscript in preparation, 2007). OC/EC analysis was performed at the University of Aveiro using a thermo-optical method similar to that in use in the IMPROVE network [Chow et al., 1993]. The details of this method as well as the evaluation of its inherent uncertainties are given by Pio et al. [2007]. The analyses of levoglucosan and cellulose were performed at the Vienna University of Technology. Cellulose was determined with the method of Puxbaum and Tenze-Kunit [2003]. Levoglucosan was determined with a gradient-
HPLC method with electrochemical detection (ED40, Dionex) using a CarboPac PA10 column (Dionex) for carbohydrate analysis. The method is described in detail by Puxbaum et al. [2007].

[12] In this integrated source apportionment approach the total aerosol carbon (TC) is divided into the following basic classes which are well defined and distinguishable by origin on the basis of the available analytical data and other information. They include biomass burning (index BB), fossil fuel (index FF) and biogenic primary (index Bio) fractions. In this way elemental carbon (EC) determined directly by the thermo-optical method is subdivided in two subcategories, $\mathrm{EC}_{\mathrm{BB}}$ emitted by biomass burning which is derived from $\mathrm{OC} / \mathrm{EC}$ emission factors reported for wood burning in the literature and $\mathrm{EC}_{\mathrm{FF}}$ released from fossil fuel combustion obtained by subtraction $\mathrm{EC}_{\mathrm{BB}}$ from measured EC. Organic carbon (OC) measured by the thermo-optical method is subdivided into three primary subcategories $\left(\mathrm{OC}_{\mathrm{FF}}, \mathrm{OC}_{\mathrm{BB}}\right.$, and $\left.\mathrm{OC}_{\mathrm{bio}}\right)$ and two secondary $\left(\mathrm{SOA}_{\mathrm{FF}}\right.$ and $\mathrm{SOA}_{\text {nonfossil). }}$

[13] $\mathrm{OC}_{\mathrm{FF}}$ represents the primary organic aerosol carbon related to fossil fuel combustion, and is derived from $\mathrm{EC}_{\mathrm{FF}}$ by using $(\mathrm{OC} / \mathrm{EC})_{\text {prim }}$ ratios reported for fossil fuel combustion in the literature which are also commonly used for SOA estimation.

[14] $\mathrm{OC}_{\mathrm{BB}}$ is primary organic aerosol carbon from biomass burning which is calculated from measured levoglucosan concentrations and reported OC/levoglucosan emission factors.

[15] $\mathrm{OC}_{\text {bio }}$ corresponds to primary organic aerosol carbon emitted from natural (vegetation) sources, and is derived from measured cellulose concentrations.

[16] Secondary organic aerosol fraction is partitioned between fossil and nonfossil derived SOA: $\mathrm{SOA}_{\text {nonfossil }}$ corresponding to secondary organic aerosol carbon formed from VOCs emitted by vegetation and/or biomass burning is derived as:

$$
\begin{aligned}
\mathrm{SOA}_{\text {nonfossil }} \times \mathrm{f}_{\mathrm{M}(\text { nonfossil })=} & \mathrm{TC} \times \mathrm{f}_{\mathrm{M}}-\mathrm{OC}_{\mathrm{bio}} \times \mathrm{f}_{\mathrm{M}(\text { bio })} \\
& -\left(\mathrm{OC}_{\mathrm{BB}}+\mathrm{EC}_{\mathrm{BB}}\right) \times \mathrm{f}_{\mathrm{M}(\mathrm{BB})} \\
& -\left(\mathrm{OC}_{\mathrm{FF}}+\mathrm{EC}_{\mathrm{FF}}+\mathrm{SOA}_{\mathrm{FF}}\right) \times \mathrm{f}_{\mathrm{M}(\mathrm{FF})}
\end{aligned}
$$

where $\mathrm{TC}$ and $\mathrm{OC}_{\mathrm{Bio}}, \mathrm{OC}_{\mathrm{BB}}, \mathrm{EC}_{\mathrm{BB}}$ are measured and derived concentration data, respectively; $\mathrm{f}_{\mathrm{M}}$ represents the ${ }^{14} \mathrm{C} /{ }^{12} \mathrm{C}$ ratio of the sample related to that present in the reference year 1950 [Szidat et al., 2004]; $\mathrm{f}_{\mathrm{M}}$ values for the subfractions $\left(f_{M(\text { nonfossil) }}, f_{M(b i o)}, f_{M(B B)}\right.$, and $f_{M(F F)}$ ) are selected on the basis of the principles set forth in subsection 2.6.

[17] $\mathrm{SOA}_{\mathrm{FF}}$ is determined as a residual term by subtracting all other components from TC. Note that it is formally included in the calculation of $\mathrm{SOA}_{\text {nonfossil, }}$ though this does not lead to a loop in the calculations since the multiplication factor $\mathrm{f}_{\mathrm{M}(\mathrm{FF})}=0$.

[18] The classification described above covers all major source processes which produce carbonaceous aerosol in the troposphere, and provides a closure for aerosol carbon. At the same time the subcategories are sufficiently lumped to be validated against regional organic aerosol climatology models. These subcategories cannot be measured directly 
but can only be inferred from combination of data from radiocarbon and organic tracer measurements. It should be noted that thermo-optical method yields elemental carbon (EC) and not BC, which is a conceptually different species [Gelencsér, 2004]. However, linking of their concentrations to other chemical species dissolves the borderline between EC and $\mathrm{BC}$, and any differences simply merge into a combined uncertainty which will be discussed in the respective subsection.

\subsection{Estimation of EC}

[19] As discussed extensively by Schmid et al. [2001] different methods give rather similar values for TC, but very different values for EC. Within CARBOSOL all samples were analyzed by one laboratory using one method [Pio et al., 2007], and so site to site comparability of EC is ensured. However, the absolute values of EC itself are more uncertain than those of TC. Given the basic observed value of $\mathrm{EC}_{\mathrm{obs}}$, we therefore calculate an uncertainty range using:

$$
\mathrm{EC}=\mathrm{EC}_{\mathrm{obs}} \times \mathrm{f}_{\mathrm{EC}}
$$

where $f_{E C}$ is a factor between 0.75 to 1.25 (central value 1.0), designed to encompass biases and uncertainties associated with determinations of EC. It is well known that elemental carbon concentrations are highly dependent on the method used for their determination. A comprehensive round robin study on EC in an urban aerosol sample revealed more than a factor of 2 differences between concentrations measured by various techniques [Schmid et al., 2001]. Since the thermal-optical technique we applied for EC determination is one the most widely accepted, we slightly reduced this error range. Given EC; we then derive $\mathrm{OC}$ as:

$$
\mathrm{OC}=\mathrm{TC}-\mathrm{EC}
$$

\subsection{Estimation of $\mathbf{E C}_{\mathrm{BB}}$}

[20] OC mass emission factors and OC/EC ratios for hardwood and softwood burning are available in the literature [Oros and Simoneit, 2001a, 2001b]. Unfortunately, much depends on the analytical method used to determine EC concentrations, which itself can introduce a factor of 5-10 uncertainty into the estimation. Traditional thermal methods for OC/EC determination had been optimized for the determination of graphitic diesel soot particles, therefore they are unsuitable for the analysis of biomass smoke which is known to be almost devoid of polycrystalline graphitic structures [Martins et al., 1998]. Watson et al. [2001] reported $\mathrm{OC} / \mathrm{EC}$ ratios as low as 4.2 for residential wood burning, and 14.5 for forest fires using a more reliable thermal-optical method, though the number of fire tests was extremely limited. Kupiainen and Klimont [2005] combined a literature review of $\mathrm{OC} / \mathrm{EC}$ ratios with details of the European emissions activities, and estimated a ratio of about 2.6:1 for biomass burning sources. One of the most recent and extensive study on emission factors using the most reliable method for the OC-EC split (basically identical to the method used for EC determination within CARBOSOL) reported a range between 1 and 15, centered around 6 [Chow et al., 2004]. Thus we accepted this value as the central value to estimate $\mathrm{EC}_{\mathrm{BB}}$ from $\mathrm{OC}_{\mathrm{BB}}$ concentration, with a range between 2.5 and 10 .

\subsection{Estimation of $\mathrm{OC}_{\mathrm{FF}}$}

[21] The estimation of $\mathrm{OC}_{\mathrm{FF}}$ from $\mathrm{EC}_{\mathrm{FF}}$ and reported $\mathrm{OC} / \mathrm{EC}$ ratios is more straightforward than that for the corresponding biomass burning fractions. Indeed there are much more data available in the literature for fossil fuel primary $\mathrm{OC} / \mathrm{EC}$ ratios since they form the basis for the estimation of SOA contribution to organic aerosol mass (for a summary see Gelencsér [2004]). Furthermore uncertainties resulting from the application of different methodologies for OC/EC determination are less critical for fossil fuel than for biomass smoke, since diesel soot resembles more closely to elemental (graphitic) carbon for which most methods were optimized [Schmid et al., 2001]. In our calculations, however, care has to be taken not to rely unconditionally on $\mathrm{OC} / \mathrm{EC}$ primary ratios reported for urban aerosol. This is because these ratios also include nonfossil combustion and other sources (e.g., biomass burning and food preparation) which do not fit our concept relying strongly on radiocarbon measurements. Results from tunnel experiments, or direct emission measurements much better fit for this purpose, since they include purely fossil fuel combustion sources. With this in mind, OC/EC ratios for tunnel experiments range from 0.76 [Gillies et al., 2001] in the United States down to 0.3 for heavy-duty diesel vehicles in Vienna [Laschober et al., 2004]. Unpublished results of road tunnel measurements in Birmingham (with 90\% of fleet running on gasoline) using thermal-optical methodology indicated $\mathrm{OC} / \mathrm{EC}$ ratios between 0.48 and 0.81 (average 0.58) (C. Pio, unpublished results, 2003). It has been very recently anticipated that these low values refer to PM2.5 aerosol since in the coarse fraction additional OC comes from abrasion of street surface, brake linings and tires thus raising PM10 OC/EC values well above unity (H. Puxbaum, private communication, 2005). Kupiainen and Klimont's [2005] study estimated a ratio of about $0.71: 1$ for fossil fuel sources in the "old" 15 EU countries, but a ratio of 1.2 for the new member states. For our calculations we accept the average value of 0.58 from the Birmingham study, with a corresponding range $(0.48-1.2)$.

[22] Since, however, the calculation is based on OC/EC primary ratio one might argue that differences in scavenging ratios for the two species can undermine the validity of the calculations at high-elevation sites which are very sensitive to deposition processes. Indeed, there have been numerous experimental studies proving that scavenging efficiencies for EC and OC are markedly different, which in turn can affect their mass concentration at remote sites where longrange transport is significant. This should mean, for example, that the concept of estimation of SOA formation based $\mathrm{OC} / \mathrm{EC}$ ratio gradually breaks down moving away from the source regions, so it should not be reliably used for remote sites, especially if they are at high elevations.

[23] On the other hand, the concept of our study is retrospective in the sense that it tries to reconstruct major primary aerosol components from different sources from measured mass concentrations of specific conservative tracers. This concept does not require that the scavenging efficiencies of EC and (total) OC be the same (which are not), but only assumes that the scavenging efficiency of 
primary $\mathrm{OC}_{\mathrm{FF}}$ emitted by fossil fuel combustion is approximately the same as that of EC which is coemitted with it. Therefore there is a fairly good probability that they will soon form internally mixed particles, and whatever happens to them upon further ageing, will happen to both approximately at the same proportion [see Tsyro et al., 2007]. So we believe it is not unrealistic to assume that differences in scavenging efficiencies may not significantly affect these calculations. Perhaps it adds some uncertainty to them, but the largest uncertainties remain those associated with primary emission ratios.

\subsection{Estimation of $\mathrm{OC}_{\mathrm{BB}}$}

[24] On a mass basis, the largest source of biomass burning emission in Europe is wood burning in stoves and fireplaces used for residential heating and cooking. In summer, wood is also burned in open fires for grilling. In certain periods of the year, under severe drought conditions persistent in southern Europe, wildfires occur sporadically which sometimes impact quite large areas. Agricultural waste burning is now prohibited in most European countries, yet it is frequently practiced in many of them, particularly in spring and autumn. In the selection of pooled aerosol samples, however, these periods were omitted, therefore emission of levoglucosan and OC from wood burning are used in our calculations. Levoglucosan is a tracer for cellulose pyrolysis but unlike other molecular tracers has the unique property of being emitted at an exceptionally large rate comparable in magnitude to total carbon mass emission [Simoneit et al., 1999]. Albeit emission factors of both OC and levoglucosan vary by orders of magnitude depending on the type of the wood burned and the conditions of burning [Oros and Simoneit, 2001b], the mass emission factor of levoglucosan relative to OC is more constrained [Fine et al., 2002]. Although OC in itself is not a conservative quantity, if only its primary aerosol component is considered and assumed to be preserved in the atmosphere, the ratios of the emissions factors can also be applied to aerosol mass concentration. Test combustion in fireplaces and stoves in the US resulted in a mean value of 7.35 for the OC/levoglucosan mass emission ratio [Fine et al., 2004] which has essentially been confirmed in test burns of beech and spruce in a tile oven [Schmidl, 2005]. Higher ratios (e.g., 12.5) are probably more typical for open fires, and may also in part reflect the experimental difficulties in emission measurements [Andreae and Merlet, 2001]. Therefore as a central value we take the factor of 7.35 , and set the lower and upper limit to 6 and 12.5, respectively.

\subsection{Estimation of $\mathrm{OC}_{\mathrm{bio}}$}

[25] Since it was assumed that a major fraction of cellulose found in atmospheric aerosol comes from decomposition of leaves, the contribution of plant debris to fine organic aerosol was suggested to be estimated simply by the multiplication of total cellulose mass concentrations by the factor of 2 [Puxbaum and Tenze-Kunit, 2003]. The fraction that was measured is free cellulose, which forms on average about $70 \%$ of total cellulose. Furthermore, for the carbon mass balance the amount of plant debris has to be expressed in carbon equivalent, which is about $57 \%$ of the total mass. Thus measured cellulose concentrations were multiplied by a factor of 1.6 to estimate the contribution of $\mathrm{OC}_{\mathrm{bio}}$ on a carbon equivalent basis. It should be added that plant debris from leaves is clearly not the only contributor to primary biological particles [Matthias-Maser and Jaenicke, 1994]; thus other biogenic sources, e.g., with no cellulose, based on protein may add to the $\mathrm{OC}_{\mathrm{bio}}$. Degrading plant material exhibits a lower cellulose content than green leaves, as cellulose is preferentially consumed by fungi and other degrading organisms, this would enhance the conversion factor. Also nearly pure cellulose containing plant parts may contribute to atmospheric cellulose levels (e.g., plant hairs or seeds with pure cellulose containing parachute like tuffs); for those the cellulose content approaches $100 \%$. Given that the two effects may cancel to some extent, we can take the factor of 2 as the central value, noting that the accompanying uncertainty could be around a factor of 2 . Allowing for the conversion factor 1.6 discussed above, we obtain low, central and high values of $0.8,1.6$ and 3.2 for converting measured free cellulose mass concentration to $\mathrm{OC}_{\text {bio. }}$.

\subsection{Calculation of $\mathrm{SOA}_{\text {nonfossil }}$}

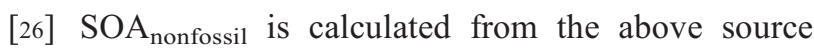
contributions by the formula specified above. $\mathrm{f}_{\mathrm{M}(\mathrm{bio})}$ is assumed to be close to the $\mathrm{CO}_{2}$ radiocarbon concentration whose $f_{M}$ value lies still slightly over the reference value from 1950 because of the enhancement of the atmospheric ${ }^{14} \mathrm{C}$ concentration by bomb-released ${ }^{14} \mathrm{C}$. The average ${ }^{14} \mathrm{C}$ signature of atmospheric $\mathrm{CO}_{2}$ for the CARBOSOL sampling years 2002, 2003 and 2004 at the Jungfraujoch is measured to be $(107 \pm 0.5) \mathrm{pmC}$ [Levin and Kromer, 2004]. The ${ }^{14} \mathrm{C}$ signature of biomass burning emissions $\left(\mathrm{f}_{\mathrm{M}(\mathrm{BB})}\right)$ is more uncertain, ranging from $f_{M}=1.07$ for burning of agricultural residues to a maximum tree signature of 1.25 [Lewis et al., 2004]. As a central value we adapted $\mathrm{f}_{\mathrm{M}(\mathrm{BB})}=$ 1.15 , with the range specified above. At the other end of the scale carbonaceous emissions from fossil fuels are free of radiocarbon, and carry therefore a ${ }^{14} \mathrm{C}$ signature $\left(\mathrm{f}_{\mathrm{M}(\mathrm{FF})}\right)$ of 0 . Since we have no a priori information about the fraction of biogenic or biomass burning SOA and therefore no clear information on the ${ }^{14} \mathrm{C}$ signature of $\mathrm{SOA}_{\text {nonfossil }}$ some assumptions about $\mathrm{f}_{\mathrm{M} \text { (nonfossil) }}$ have to be made. Assuming $\mathrm{SOA}_{\text {nonfossil }}$ to be completely of recent biogenic origin $\mathrm{f}_{\mathrm{M} \text { (nonfossil) would be } 1.07 \text {, while assuming it to be produced }}$ completely by biomass burning $\mathrm{f}_{\mathrm{M} \text { (nonfossil) }}$ would be equal to $f_{M(B B)}$. On the basis of the traditional concept of SOA we adapted $\mathrm{f}_{\mathrm{M} \text { (nonfossil) }}=1.07$, noting that any contribution from biomass burning VOCs would increase this value up to $f_{M(B B)}$ resulting in a decrease of $\mathrm{SOA}_{\text {nonfossil. In the }}$ uncertainty analysis below we explore a wider range of $\mathrm{f}_{\mathrm{M} \text { (nonfossil). }}$

\subsection{Uncertainty Analysis}

[27] Table 1 summarizes the eight "uncertain" inputs to the source apportionment (SA) calculation, along with their low, central and high values. It is clear that the SA calculation involves many steps, each of which has substantial uncertainties. In order to tackle the multitude of possible combinations of these uncertain parameters, we have made use of an effective statistical approach known as Latin-hypercube sampling (LHS [e.g., Iman et al., 1981]). LHS approaches are somewhat similar to Monte Carlo (MC) calculations, and allow vast numbers of combinations 
Table 1. Summary of Low, Central, and High Factors Used in Deriving the Source Apportionment Contributions and as Input Parameters to the Uncertainty Analysis ${ }^{\mathrm{a}}$

\begin{tabular}{llll}
\hline \multicolumn{1}{c}{ Parameters } & Low & Central & \multicolumn{1}{c}{ High } \\
\hline EC error factor $^{\mathrm{b}}$ & 0.75 & 1.0 & 1.25 \\
${\text { Levoglucosan to } \mathrm{OC}_{\mathrm{bb}} \text { ratio }}$ & 0.08 & 0.136 & 0.167 \\
$\mathrm{OC}_{\mathrm{bb}}$ to $\mathrm{EC}_{\mathrm{bb}}$ ratio & 1.0 & 6.0 & 15.0 \\
$\mathrm{OC}_{\mathrm{ff}}$ to $\mathrm{EC}_{\mathrm{ff}}$ ratio & 0.48 & 0.58 & 1.2 \\
$\mathrm{OC}_{\mathrm{bio}}$ to cellulose ratio & 0.8 & 1.6 & 3.2 \\
$\mathrm{f}_{\mathrm{M}(\mathrm{BB})}$ & 107 & 115 & 125 \\
$\mathrm{f}_{\mathrm{M}(\text { nonfossil })}^{\mathrm{c}}$ & 107 & 107 & no single value \\
$\mathrm{f}_{\mathrm{M}} \mathrm{f}_{\mathrm{M}}^{\mathrm{c}} \%$ & -5 & 0 & +5 \\
\hline
\end{tabular}

${ }^{\mathrm{a}} \mathrm{See}$ text for details.

${ }^{\mathrm{b}} \mathrm{EC}$ values multiplied by given factor.

${ }^{c} f_{M(n o n f o s s i l)}$ constrained to be $<\mathrm{f}_{\mathrm{M}(\mathrm{BB})}$.

${ }^{\mathrm{d}}$ Maximum analytical error of the measured $\mathrm{f}_{\mathrm{M}}$ values, reaching up to $10 \%$ at $\mathrm{SBO}$.

of input variables to be computed. An MC simulation would involve testing all possible combinations of input parameters. LHS provides a much more effective way of sampling the data, and for our purposes provides essentially the same results as a full MC analysis.

[28] For each uncertain input parameter, $P$, we have set up a frequency distribution of $N$ possible values, e.g., $\mathrm{P}_{1}, \mathrm{P}_{2},$. . $\mathrm{P}_{\mathrm{N}}$. This is done for each of the parameters shown in Table 1. With MC simulation we would require $8^{\mathrm{N}}$ calculations to combine all the eight factors of Table 1, and this proved prohibitive in terms of CPU time for this study. With LHS we can achieve very similar results with just $N$ calculations (here, we use $N=3000$, and make use of the software for improved distributed hypercube sampling from http://people.scs.fsu.edu/ burkardt/f_src/ihs/ihs.html).

[29] Ideally one would like the input parameters to be specified with a well defined statistical distribution, e.g., a normal distribution. Unfortunately, there are so few data upon which to base our parameters that a simpler procedure is chosen. Instead we have assigned parameters equally between the low and central, and between the central and high values of Table 1 .

[30] Thus, in essence we have superimposed two "tophat" functions, with one top-hat function between the min and central values, and one between the central and high. For $\mathrm{f}_{\mathrm{M} \text { (nonfossil) }}$ the high value is constrained to be equal to the $\mathrm{f}_{\mathrm{M}(\mathrm{BB})}$ value, and the central value defined as $0.5 \times$

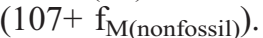

[31] A great advantage of the LHS (or MC) approach is that combinations of parameters which are very unlikely (e.g., that only the minimum-possible values from each parameter were used) will represent only a small percentage of the output. Specifically, the chances of this happening for $\mathrm{N}$ runs would then be about $1 / \mathrm{N}$, in our case $1 / 3000$. Some combinations of parameters even lead to negative concentrations and are thus impossible; these combinations are simply rejected from the analysis. The remaining valid combinations can be presented graphically as a frequency distribution of possible solutions to the SA problem we have set up.

\section{Results and Discussion}

[32] The CARBOSOL aerosol data used in our calculations are given in Table 2. Data for those filters were used for which pooled radiocarbon measurements were available. For AVE, KPZ and SBO pooled samples were used for ${ }^{14} \mathrm{C}$ measurements, while the determination of all other aerosol components and fractions was performed on individual filters collected weekly. Therefore weighted average mass concentrations based on individual sample volumes were calculated to make the results fit for the pooled samples. For levoglucosan and cellulose, when the mass concentrations were below the detection limit, the values of the detection limit were used in the calculations. The samples, though limited in number because of constraints on the costs of radiocarbon measurements, are thought to represent typical

Table 2. Sampling Data and Volume-Weighted Average Measured Mass Concentrations of Total Carbon (TC), Elemental Carbon (EC), Organic Carbon (OC), Levoglucosan, Cellulose, as Well as the Share of Modern Carbon $\left(\mathrm{f}_{\mathrm{M}}\right)$ for Seasonal Aerosol Samples for All Sites ${ }^{\mathrm{a}}$

\begin{tabular}{|c|c|c|c|c|c|c|c|c|}
\hline$\underline{\text { Site }}$ & Season & Sampling Date & $\mathrm{TC}, \mu \mathrm{gC} / \mathrm{m}^{3}$ & $\mathrm{EC}, \mu \mathrm{gC} / \mathrm{m}^{3}$ & $\mathrm{OC}, \mu \mathrm{gC} / \mathrm{m}^{3}$ & Levoglucosan, $\mathrm{ng} / \mathrm{m}^{3}$ & Cellulose, $\mathrm{ng} / \mathrm{m}^{3}$ & $f_{M}$ \\
\hline AVE & winter & $\begin{array}{l}\text { Dec } 2002, \text { Jan-Feb } 2003 \text {, } \\
\text { Dec } 2003 \text { to Jan } 2004\end{array}$ & 14.1 & 1.80 & 12.3 & 1220 & 107 & $0.92 \pm 0.009$ \\
\hline AVE & summer & $\begin{array}{l}\text { Jul-Aug 2002, } \\
\text { May-Aug 2003, } \\
\text { Jun } 2004\end{array}$ & 4.04 & 0.57 & 3.47 & 38 & 39 & $0.78 \pm 0.006$ \\
\hline PDD & winter & $\begin{array}{l}\text { Dec 2002, Jan } \\
\quad \text { and Dec } 2003\end{array}$ & 0.86 & 0.21 & 0.65 & 10.9 & 15 & $0.62 \pm 0.005$ \\
\hline PDD & summer & Jun and Jun 2003 & 4.92 & 0.29 & 4.63 & 7.4 & 125 & $0.87 \pm 0.004$ \\
\hline SIL & winter & $\begin{array}{l}\text { Dec 2002, Jan } \\
\quad \text { and Dec } 2003\end{array}$ & 1.66 & 0.28 & 1.38 & 32 & 21 & $0.79 \pm 0.004$ \\
\hline SIL & summer & Jun to Aug 2003 & 4.05 & 0.25 & 3.80 & 10.4 & 134 & $0.83 \pm 0.004$ \\
\hline SBO & winter & Oct-Dec 2002 & 0.21 & 0.02 & 0.19 & $2.7^{\mathrm{b}}$ & 10 & $0.72 \pm 0.04$ \\
\hline SBO & summer & May-Jun 2003 & 1.56 & 0.12 & 1.44 & 4.5 & 30 & $0.83 \pm 0.017$ \\
\hline KPZ & winter & $\begin{array}{l}\text { Nov-Dec 2002, } \\
\text { Feb and Dec } 2003, \\
\text { Jan-Feb } 2004\end{array}$ & 10.7 & 1.74 & 8.91 & 585 & 90 & $0.78 \pm 0.006$ \\
\hline KPZ & summer & $\begin{array}{l}\text { Jul to Aug 2002, } \\
\text { May 2003, } \\
\text { Aug-Sep } 2003\end{array}$ & 5.04 & 0.53 & 4.52 & 44.1 & 153 & $0.88 \pm 0.012$ \\
\hline
\end{tabular}

${ }^{\mathrm{a}}$ For AVE, KPZ and SBO pooled samples were used for ${ }^{14} \mathrm{C}$ measurements, while the determination of all other aerosol components and fractions was performed on individual filters collected weekly and their concentrations are reported as volume-weighted average mass concentrations. (An outlier was rejected because of identified contamination problem in December 2002 at SBO.)

${ }^{\mathrm{b}}$ Including analytical uncertainty. 
Table 3. Estimated Mass Concentrations of Elemental Carbon (EC), Organic Carbon (OC), and Secondary Organic Aerosol Carbon (SOA) Subcategories ${ }^{\mathrm{a}}$

\begin{tabular}{|c|c|c|c|c|c|c|c|c|}
\hline$\underline{\text { Site }}$ & Season & $\begin{array}{l}\mathrm{OC}_{\mathrm{BB}}, \\
\mathrm{ngC} / \mathrm{m}^{3}\end{array}$ & $\begin{array}{l}\mathrm{EC}_{\mathrm{BB}}, \\
\mathrm{ngC} / \mathrm{m}^{3}\end{array}$ & $\begin{array}{l}\mathrm{OC}_{\mathrm{FF}}, \\
\mathrm{ngC} / \mathrm{m}^{3}\end{array}$ & $\begin{array}{l}\mathrm{EC}_{\mathrm{FF}}, \\
\mathrm{ngC} / \mathrm{m}^{3}\end{array}$ & $\begin{array}{l}\mathrm{OC}_{\text {bio, }}, \\
\mathrm{ngC} / \mathrm{m}^{3}\end{array}$ & $\begin{array}{c}\mathrm{SOA}_{\text {nonfossil }} \\
\mathrm{ngC} / \mathrm{m}^{3}\end{array}$ & $\begin{array}{l}\mathrm{SOA}_{\mathrm{FF}}, \\
\mathrm{ngC} / \mathrm{m}^{3} \\
\end{array}$ \\
\hline AVE & winter & 8960 & 1490 & 178 & 307 & 171 & 699 & 2270 \\
\hline AVE & summer & 279 & 47 & 301 & 518 & 62 & 2540 & 296 \\
\hline PDD & winter & 80 & 13 & 114 & 197 & 24 & 374 & 57 \\
\hline PDD & summer & 54 & 9 & 160 & 276 & 200 & 3720 & 504 \\
\hline SIL & winter & 235 & 39 & 140 & 241 & 34 & 900 & 72 \\
\hline SIL & summer & 76 & 13 & 138 & 237 & 214 & 2850 & 523 \\
\hline SBO & winter & 22 & 4 & 9 & 16 & 16 & 97 & 45 \\
\hline SBO & summer & 33 & 6 & 66 & 114 & 48 & 1130 & 165 \\
\hline KPZ & winter & 4300 & 717 & 593 & 1020 & 144 & 2240 & 1630 \\
\hline KPZ & summer & 324 & 54 & 273 & 471 & 245 & 3480 & 191 \\
\hline
\end{tabular}

${ }^{a}$ Indices are as follows: BB, biomass burning; FF, fossil fuel; bio, biogenic. Only concentrations calculated with central values are given. For details see text.

characteristic winter and summer aerosol conditions for the five CARBOSOL sites. Note that the ${ }^{14} \mathrm{C}$ measurements at SBO in winter have been done specifically for a sampling time where the station was most likely to be in the free troposphere, thus reflecting the tropospheric background. From Table 2 it is straightforward to obtain the basic source apportionment for the samples selected following the considerations set forth above, using the central estimates (Table 1) to obtain our "best estimate" of the different contributions. We discuss these best estimate data first (section 3.1) in order to outline the main features of the results, and then discuss the robustness of these conclusions with an analysis of the uncertainties (section 3.2).

\subsection{Best Estimate Results}

[33] The estimated mass concentrations corresponding to the major source categories thus obtained for this "best estimate" case are reported in Table 3. In Table 3 the 5th and 95th percentiles derived from the statistical analysis of uncertainties (section 3.2) are also reported. From that it is then possible to evaluate the relative importance of primary versus secondary sources, fossil fuel combustion versus biomass burning, and to obtain typical seasonal averages which are likely to be characteristic of most of the lower troposphere over Europe.

[34] In Table 4, the relative contributions of all source categories of OC and EC are expressed by site and season in percentage of TC. The results suggest that EC emissions in Europe are dominated by fossil fuel. The share of fossilderived EC is between 86 and 97\% at high-elevation sites, but $59 \%$ at $\mathrm{KPZ}$ and as low as $17 \%$ at AVE in winter where biomass burning dominates. This finding agrees with those of Hamilton and Mansfield [1991] who found that most BC in summer came from diesel combustion. The minor differences may be explained by the technological development diesel engines underwent in the past 15 years, clearly offsetting any increase that would have resulted from the increase of the number of light- and heavy-duty diesel vehicles in Europe. Typically at the low-elevation sites in winter the average mass concentrations of EC are a factor of three higher than those in summer. On the contrary, at the two elevated sites SIL and PDD winter and summer values become comparable, and at SBO, under the conditions of the free troposphere, the winter value is only $16 \%$ of that of summer.

[35] Not surprisingly, primary organic aerosol emission from biomass burning established a very significant contribution at all sites in winter, ranging from $11 \%$ at SBO (free tropospheric conditions) to the extremity of the very high local contribution at AVE (64\%). The two elevated rural sites PDD and SIL exhibited nonnegligible biomass burning primary components ( 9 and 14\%, respectively), which, with $\mathrm{EC}_{\mathrm{BB}}$ added approximated $11-16 \%$ of the total carbonaceous mass. In summer, the relative shares of $\mathrm{OC}_{\mathrm{BB}}$ and $\mathrm{EC}_{\mathrm{BB}}$ become practically negligible (with the exception of AVE and KPZ), thus biomass burning represented a primary carbonaceous aerosol source with atmospheric concentrations of only $11-14 \%$ of those of fossil fuel combustion at elevated sites. At the rural site of KPZ this value was $50 \%$, indicating a nonnegligible contribution from this source. In winter the overall contribution of biomass burning $\left(\mathrm{OC}_{\mathrm{BB}}+\mathrm{EC}_{\mathrm{BB}}\right)$ far exceeds that of fossil fuel combustion $\left(\mathrm{OC}_{\mathrm{FF}}+\mathrm{EC}_{\mathrm{FF}}\right)$ at low-level sites. On the contrary, at

Table 4. Relative Share of OC and EC Source Categories Within Total Carbon (TC)

\begin{tabular}{|c|c|c|c|c|c|c|c|c|}
\hline Site & Season & $\mathrm{OC}_{\mathrm{BB}}, \%$ & $\mathrm{EC}_{\mathrm{BB}}, \%$ & $\mathrm{OC}_{\mathrm{FF}}, \%$ & $\mathrm{EC}_{\mathrm{FF}}, \%$ & $\mathrm{OC}_{\text {bio }}, \%$ & $\mathrm{SOA}_{\text {nonfossil }}, \%$ & $\mathrm{SOA}_{\mathrm{FF}}, \%$ \\
\hline AVE & winter & $64(52-69)$ & $11(4.0-12)$ & $1(0.6-7.8)$ & $2(1.0-10)$ & $1(0.7-2.3)$ & $5(1.8-23)$ & $16(1.7-20)$ \\
\hline AVE & summer & $7(5.7-11)$ & $1(0.5-5.0)$ & $7(4.6-14)$ & $13(7.9-16)$ & $2(0.8-2.9)$ & $63(52-65)$ & $7(1.8-19)$ \\
\hline PDD & winter & $9(7.1-14)$ & $2(0.6-6.5)$ & $13(8.7-21)$ & $23(15.4-27)$ & $3(1.5-5.3)$ & $44(33-47)$ & $7(1.2-21)$ \\
\hline PDD & summer & $1(0.9-1.7)$ & $0(0.1-0.7)$ & $3(2.3-6.7)$ & $6(4.2-6.9)$ & $4(2.2-7.7)$ & $76(66-78)$ & $10(6.3-19)$ \\
\hline SIL & winter & $14(12-23)$ & $2(1.0-10)$ & $8(3.6-14)$ & $15(5.7-18)$ & $2(1.0-3.8)$ & $54(37-57)$ & $4(1.0-21)$ \\
\hline SIL & summer & $2(1.5-2.9)$ & $0(0.1-1.3)$ & $3(2.3-7.0)$ & $6(4.2-7.3)$ & $5(2.9-10)$ & $70(60-73)$ & $13(8.8-21)$ \\
\hline $\mathrm{SBO}$ & winter & $11(5.8-11)$ & $2(0.5-4.8)$ & $5(2.5-10)$ & $8(4.1-11)$ & $8(4.1-14)$ & $46(37-56)$ & $22(13-31)$ \\
\hline SBO & summer & $2(1.5-3.0)$ & $0(0.1-1.3)$ & $4(2.9-8.7)$ & $7(5.4-9.0)$ & $3(1.7-5.8)$ & $72(61-77)$ & $11(3.5-22)$ \\
\hline KPZ & winter & $40(33-56)$ & $7(2.7-13)$ & $6(1.6-13)$ & $10(2.6-16)$ & $1(0.7-2.6)$ & $21(4.1-31)$ & $15(3.2-28)$ \\
\hline KPZ & summer & $6(5.3-10)$ & $1(0.4-4.7)$ & $5(3.0-9.8)$ & $9(5.0-11)$ & $5(2.7-9.2)$ & $69(57-71)$ & $4(1.0-15)$ \\
\hline
\end{tabular}

${ }^{\mathrm{a}}$ Indices are the same as in Table 3 . In parentheses the 5th and 95th percentiles are given as derived from the LHS statistical analysis. 


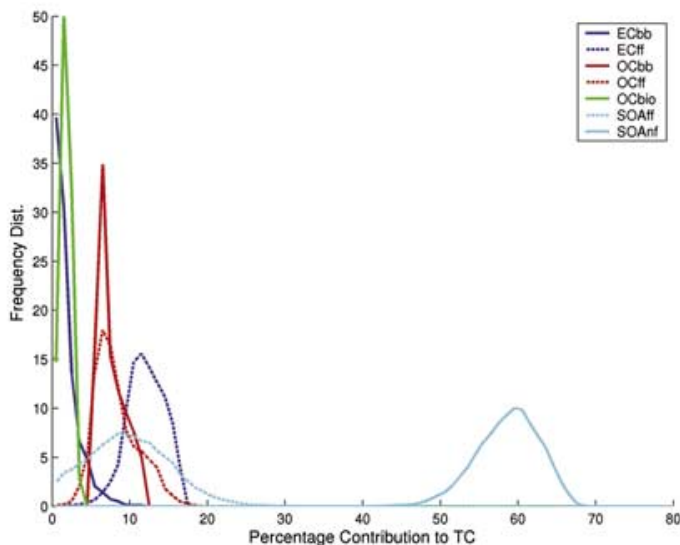

(a) AVE, Summer

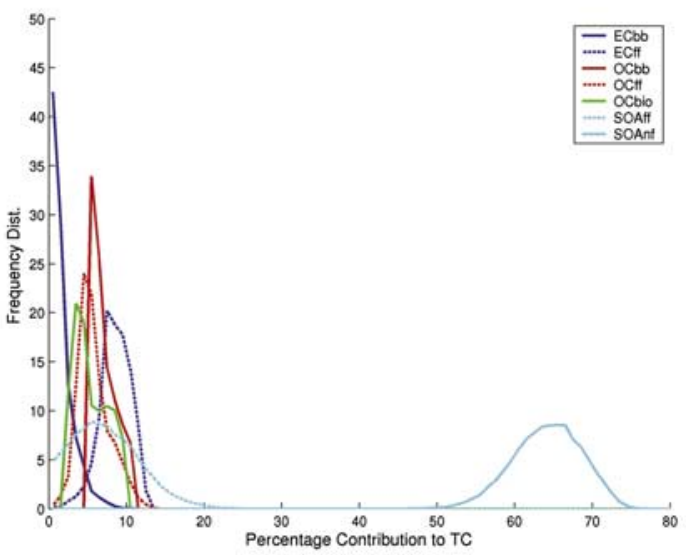

(c) KPZ, Summer

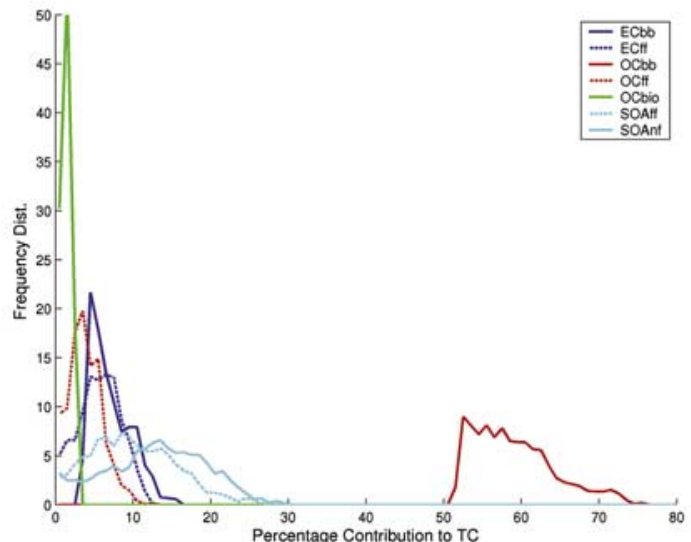

(b) AVE, Winter

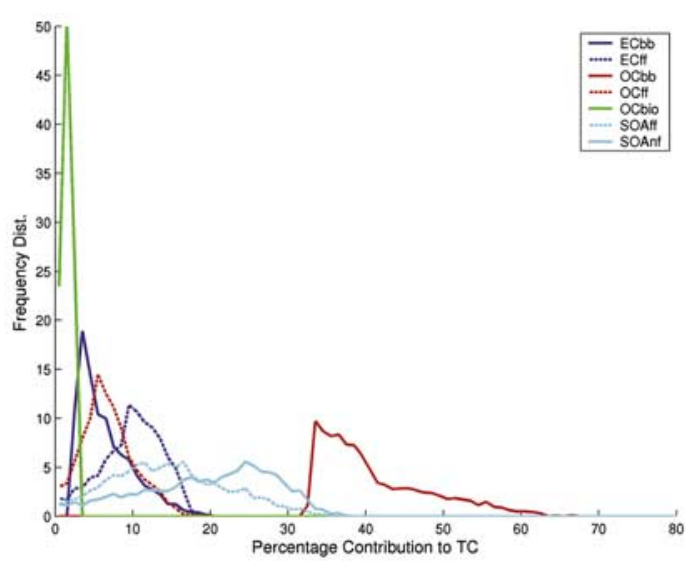

(d) KPZ, Winter

Figure 1. Probability distributions of source contributions to TC for low-level sites (a and b) Aveiro (AVE) and (c and d) K-Puszta (KPZ) for summer and winter, respectively.

elevated sites the latter was more significant. These differences between the low-level and elevated sites can be partly explained by the higher scavenging ratios of $\mathrm{OC}_{\mathrm{BB}}-\mathrm{EC}_{\mathrm{BB}}$ compared to $\mathrm{OC}_{\mathrm{FF}}-\mathrm{EC}_{\mathrm{FF}}$.

[36] For all sites and seasons, SOA represents a very important fraction of aerosol carbon mass $(21-86 \%)$. While this was expected for summer, the surprisingly high contributions in winter (up to $68 \%$ at $\mathrm{SBO}$ ), including those obtained for near-source areas (21 and 36\% for AVE and $\mathrm{KPZ}$, respectively), as well as the very high $\mathrm{SOA}_{\mathrm{FF}}$ (up to $22 \%$ ) at SBO necessitates a statement about the nature of SOA. Thus in the context of this paper SOA does not corresponds to the subset of organic aerosol generally meant in aerosol science. Above the traditional concept (condensation of photo-oxidation products of VOCs, primarily terpenes) our SOA includes condensation of directly emitted semivolatile organic compounds at low ambient temperatures (since emission ratios are usually defined for ambient temperature), and also covers primary emissions from nonspecified sources, either fossil or nonfossil. While the inclusion of the latter is clearly an imperfection of the concept itself, one could argue for the former as one possible mechanism of SOA formation.
According to the classical aerosol definition, primary aerosol particles are those released as particles directly from sources. However, the compounds included in our SOA definition are emitted as vapors from the sources, and experienced transformations (albeit purely physical) to become aerosolborne. On the other hand, one may feel that this fraction actually more closely belongs to primary emission than to "classical" SOA resulting from the complex interactions between various subsets of emissions (gases and vapors) and sunlight. Therefore caution should be exercised when interpreting various modeling or experimental results on SOA contributions without the knowledge on how this fraction is treated. In the light of the above the winter SOA values (both fossil and nonfossil) can possibly be attributed to their corresponding primary sources. This likely gives biomass burning an exceptionally high share in winter $(55-80 \%)$ in Europe, though the high values may slightly be reduced by the contribution of other nonspecified sources (e.g., cooking).

[37] In summer, however, this condensation process is thought to be much less significant at most sites (and may be subject to sampling artifacts), thus SOA values are thought to more closely represent the "traditional" concept of SOA. Nonfossil SOA dominates at all sites (63-76\%), 


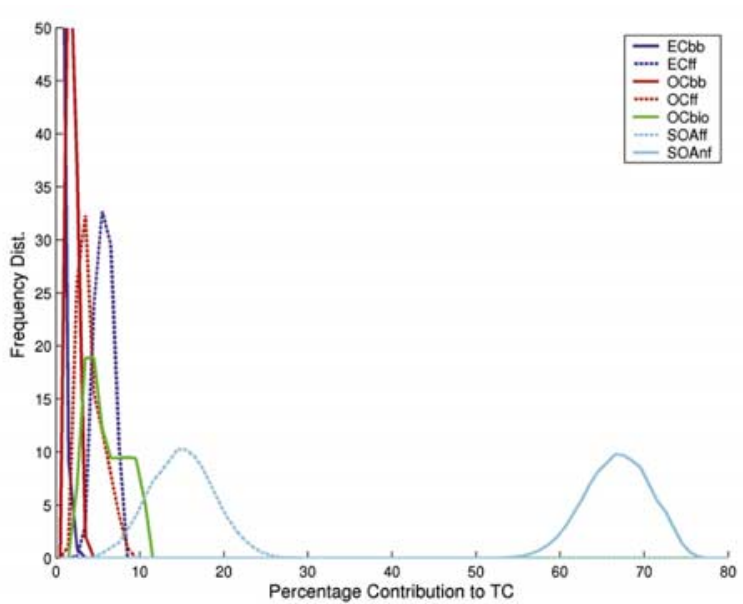

(a) SIL, Summer

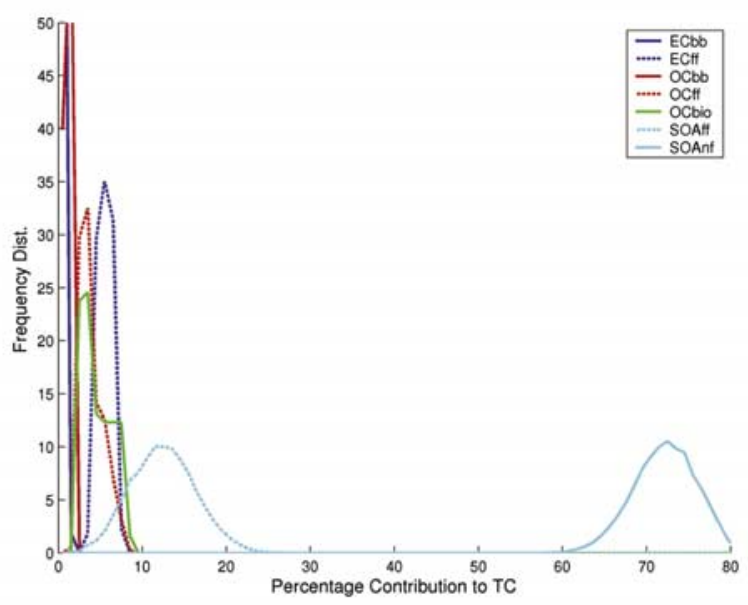

(c) PDD, Summer

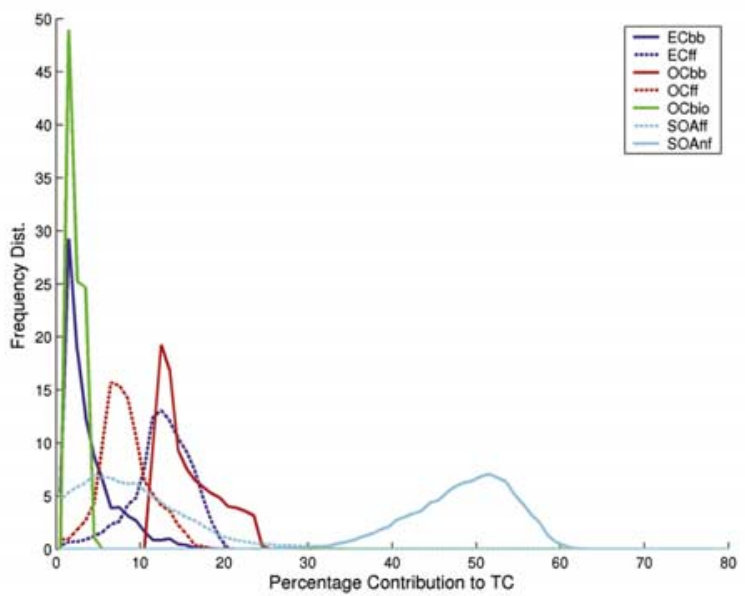

(b) SIL, Winter

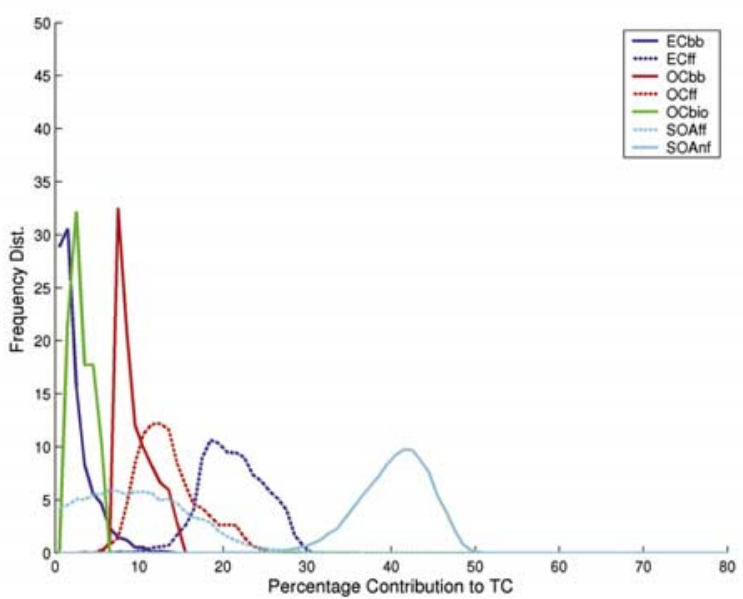

(d) PDD, Winter

Figure 2. Probability distributions of source contributions to TC for elevated sites (a and b) Schauinsland (SIL) and (c and d) Puy de Dome (PDD) for summer and winter, respectively.

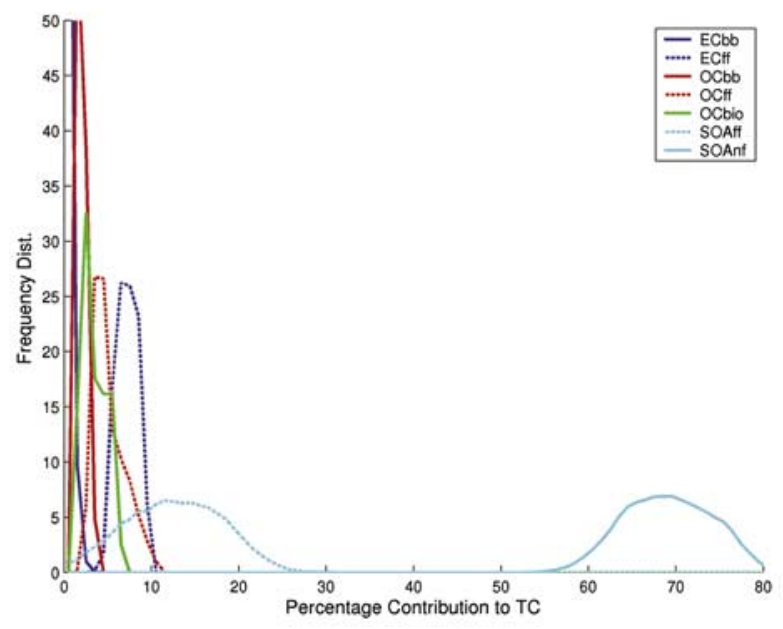

(a) SBO, Summer

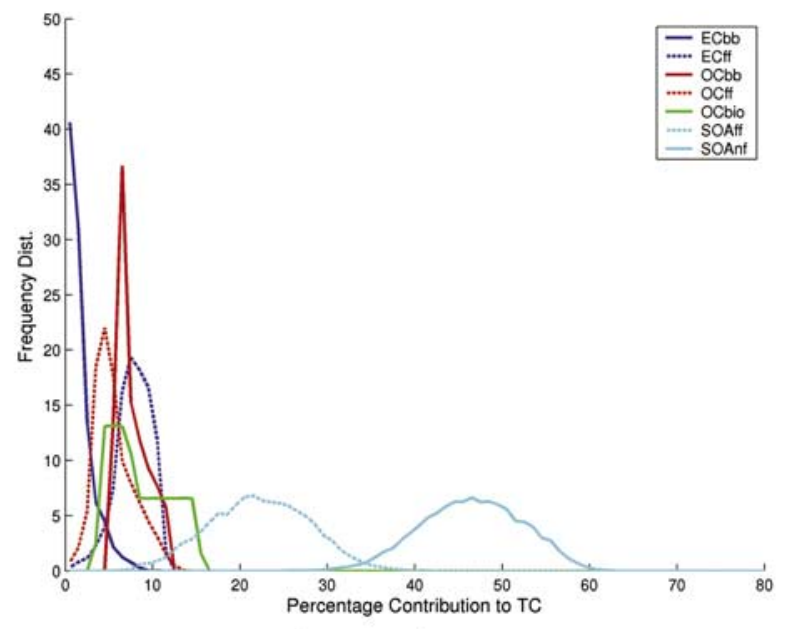

(b) SBO, Winter

Figure 3. Probability distributions of source contributions to TC for the high-alpine site Sonnblick (SBO) for (a) summer and (b) winter. 


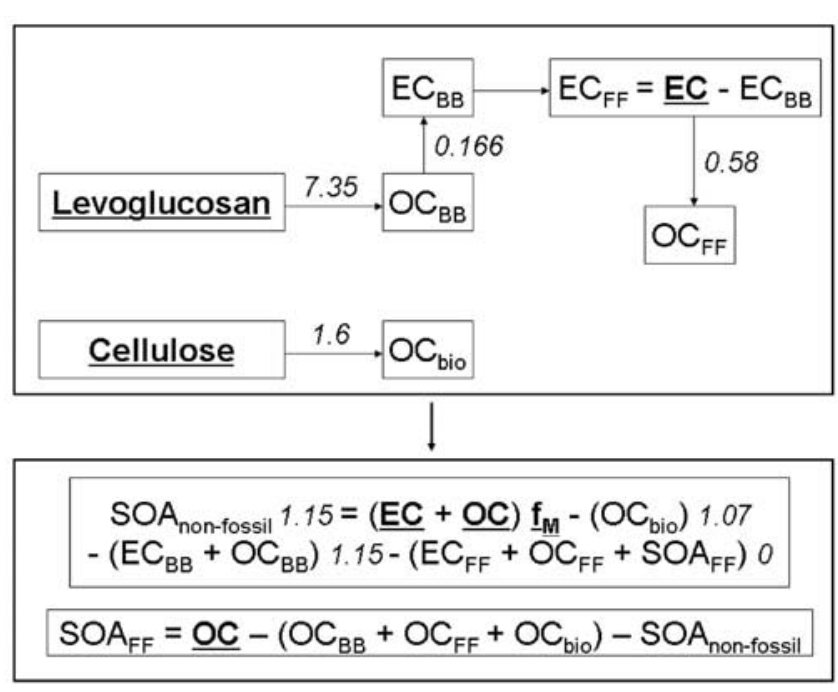

Figure 4. Scheme of the source apportionment calculations. Numbers reported on arrows are discussed in the text. Fractions reported in bold are from aerosol measurements.

probably from VOCs emitted by vegetation but some secondary contribution from biomass burning cannot be excluded, either. These findings corroborate other studies on rural aerosol which demonstrated the predominance of SOA in summer (68-78\% of OC) [Castro et al., 1999], and points to the global importance of biogenic SOA in the troposphere. $\mathrm{SOA}_{\mathrm{FF}}$ contributes a small but nonnegligible fraction to TC (4-13\%), and this statement is by far the least uncertain. However, coal combustion and other fossil related emissions may account for a part of $\mathrm{SOA}_{\mathrm{FF}}$, which thus may be a collective category for all non-traffic-related fossil combustion sources.

\subsection{Uncertainty Analysis}

[38] Figures 1-3 give the results of these uncertainty calculations for all sites. In these plots, each curve represents the probability distribution of that component's contribution to the total carbon (TC). As an example, we discuss the results of the uncertainty calculations for PDD. There the likely contribution of $\mathrm{SOA}_{\text {nonfossil }}$ to $\mathrm{TC}$ is seen to be very large in summertime (Figure $2 b$ ), with the calculations suggesting a contribution of between $60-80 \%$. The most probable contribution is seen to be just over $70 \%$. $\mathrm{EC}_{\mathrm{FF}}$ is seen to cover the range of 3-8\%, but the frequency distribution is very narrow and the most likely contribution is seen to lie around $6 \%$ of TC. Regarding the other sources, they will not be discussed in detail, but Figures 1-3 show they all make smaller but nonnegligible contributions to TC.

[39] For the same site in wintertime (Figure 2a), a similar picture emerges. The largest contributor is still $\mathrm{SOA}_{\text {nonfossil }}$, with a likely contribution of between $30-50 \%$. The reason for its abundance is discussed in subsection 3.1. Fossil sources together make very a significant overall contribution, with $\mathrm{EC}_{\mathrm{FF}}, \mathrm{OC}_{\mathrm{FF}}$ and $\mathrm{SOA}_{\mathrm{FF}}$ representing $13-30 \%$, $8-24 \%$, and zero $-23 \%$ of TC, respectively. There is also a quite robust indication that $\mathrm{OC}_{\mathrm{BB}}$ contributes to TC levels at this site in wintertime, in the range of $6-30 \%$ of TC. The central (most likely) values of all the curves shown in Figure 4 match well the "best estimate" results shown in Table 3 and discussed in section 3.1 above (the results are not identical, because the equations are nonlinear).

[40] It is important to note that the main conclusions to be derived from Figures 1-3 are quite robust. For example, $\mathrm{SOA}_{\text {nonfossil }}$ is clearly the biggest contributor to $\mathrm{TC}$ in summertime, whether we look at the central (most likely) estimates or the tails of the various curves (which represent possible but unlikely results of the LHS analysis). Given the wide range of uncertainties used in generating these figures, these results demonstrate that in general we can clearly identify the main contributors in the different seasons: the answer does not depend very much on our assumptions.

\section{Conclusions}

[41] It has been found that while fossil-related sources predominate $\mathrm{EC}$ throughout the year at all sites, the sources of $\mathrm{OC}$ are primarily biogenic and markedly different between summer and winter. In winter biomass burning primary emission is the main source, with some additional contribution from fossil fuel combustion. In contrast, in summer secondary organic aerosol (SOA) from nonfossil sources becomes predominant (63-76\% of TC), with some contribution of SOA from fossil fuel combustion. Direct contribution from biomass burning is negligible in this part of the year, being only a fraction of fossil-related primary contributions. An uncertainty analysis has been conducted, which shows that the main conclusions from this study are robust.

[42] These findings extend other studies on rural aerosol which demonstrate the predominance of SOA in summer, and point to the global importance of biogenic SOA in the troposphere. It should be recalled that even if most of the SOA is biogenic and forms from VOCs emitted by vegetation, its formation involves photo-oxidants whose levels have been strongly enhanced by human activities. Therefore, strictly speaking, most of the biogenic SOA should be considered anthropogenic by origin [see Kanakidou et al., 2000]. These aspects will also be discussed from ice core data [Legrand et al., 2007].

[43] In summary, while the results of our study are derived from a limited number of sites, and from a limited number of measurements, they clearly demonstrate the feasibility of the integrated approach to provide a bulk source apportionment of carbonaceous aerosol which can serve as validation data for atmospheric models.

[44] However, in contrast to previous studies in Europe, these sites do cover a quite wide geographical area across south-central Europe, and the relative contributions of different sources to the measured total carbon was found to be remarkably consistent between sites. Thus the findings mentioned above do provide rather powerful evidence for the relative importance of wintertime biomass burning and summertime SOA as major sources of carbonaceous aerosol in Europe. Further, these results provide important new constraints on the results of models for carbonaceous aerosols in Europe, providing a major improvement in aerosol composition which can be directly tested [e.g., Simpson et al., 2007]. 
[45] Acknowledgments. This work was supported by the EU 5th Framework Programme (contract EVK2-0067-2001). The work of D.S. was further supported by the Cooperative Programme for Monitoring and Evaluation of the Long-Range Transmission of Air Pollutants in Europe (EMEP) under UNECE and by the Nordic Council of Ministers NORPAC Project. We thank P. Steier and the VERA-laboratory for special efforts in the AMS radiocarbon analyses.

\section{References}

Andersson-Sköld, Y., and D. Simpson (2001), Secondary organic aerosol formation in northern Europe:A model study, J. Geophys. Res., 106(D7), $7357-7374$

Andreae, M. O., and P. J. Crutzen (1997), Atmospheric aerosols: Biogeochemical sources and role in atmospheric chemistry, Science, 276(5315), $1052-1058$

Andreae, M. O., and P. Merlet (2001), Emissions of trace gases and aerosols from biomass burning, Global Biogeochem. Cycles, 15(4), 955-966.

Castro, L. M., C. A. Pio, R. M. Harrison, and D. J. T. Smith (1999), Carbonaceous aerosol in urban and rural European atmospheres: Estimation of secondary organic carbon concentrations, Atmos. Environ., 33(17), 2771-2781.

Chow, J. C., J. G. Watson, L. C. Pritchett, W. R. Pierson, C. A. Frazier, and R. G. Purcell (1993), The DRI thermal-optical reflectance carbon analysis system-Description, evaluation and applications in United States air quality studies, Atmos. Environ., Part A, 27(8), 1185-1201.

Chow, J., J. G. Watson, H. Kuhns, V. Etyemezian, D. H. Lowenthal, D. Crow, S. D. Kohl, J. P. Engelbrecht, and M. C. Green (2004), Source profiles for industrial, mobile, and area sources in the Big Bend Regional Aerosol Visibility and Observational study, Chemosphere, 54, 185-208.

Chung, S. H., and J. H. Seinfeld (2002), Global distribution and climate forcing of carbonaceous aerosols, J. Geophys. Res., 107(D19), 4407, doi:10.1029/2001JD001397.

Fine, P. M., G. R. Cass, and B. R. T. Simoneit (2002), Chemical characterization of fine particle emissions from the fireplace combustion of woods grown in the southern United States, Environ. Sci. Technol., 36, $1442-$ 1451.

Fine, P. M., G. R. Cass, and B. R. T. Simoneit (2004), Chemical characterization of fine particle emissions from the wood stove combustion of prevalent United States tree species, Environ. Eng. Sci., 21, 705-721.

Gelencsér, A. (2004), Carbonaceous Aerosol, Atmos. and Oceanogr. Sci. Libr., vol. 30, 350 pp., Springer, New York.

Gillies, J. A., A. W. Gertler, J. C. Sagebiel, and W. A. Dippel (2001), On-road particulate matter (PM2.5 and PM10) emissions in the Sepulveda tunnel, Los Angeles, California, Environ. Sci. Technol., 35, 1054-1063.

Griffin, R. J., D. R. Cocker, J. H. Seinfeld, and D. Dabdub (1999), Estimate of global atmospheric organic aerosol from oxidation of biogenic hydrocarbons, Geophys. Res. Lett., 26(17), 2721-2724.

Hamilton, R. S., and T. A. Mansfield (1991), Airborne particulate elemental carbon: its sources, transport and contribution to dark smoke and soiling, Atmos. Environ., Part A, 25, 715-723.

Iman, R. L., J. C. Helton, and J. E. Campbell (1981), An approach to sensitivity analysis of computer models: Part I-Introduction, variable selection and preliminary variable assessment, J. Qual. Technol., 13(3), $174-183$

Jang, M. S., N. M. Czoschke, S. Lee, and R. M. Kamens (2002), Heterogeneous atmospheric aerosol production by acid-catalyzed particle-phase reactions, Science, 298(5594), 814-817.

Kalberer, M., et al. (2004), Identification of polymers as major components of atmospheric organic aerosols, Science, 303, 1659-1662.

Kanakidou, M., K. Tsigaridis, F. J. Dentener, and P. J. Crutzen (2000), Human-activity-enhanced formation of organic aerosols by biogenic hydrocarbon oxidation, J. Geophys. Res., 105(D7), 9243-9254.

Kanakidou, M., et al. (2005), Organic aerosol and global climate modeling: A review, Atmos. Chem. Phys., 5, 1053-1123.

Kupiainen, K., and Z. Klimont (2005), Primary emissions of submicron and carbonaceous particles in Europe and the potential for their control, Interim Rep. IR-04-079, Int. Inst. for Appl. Syst. Anal., Laxenburg, Austria.

Laschober, C., A. Limbeck, J. Rendl, and H. Puxbaum (2004), Particulate emissions from on-road vehicles in the Kaisermühlen-tunnel (Vienna, Austria), Atmos. Environ., 38, 2187-2195.

Legrand, M., S. Preunkert, M. Schock, M. Cerqueira, A. Kasper-Giebl, J. Alfonso, C. Pio, A. Gelencsér, I. Etchevers, and D. Simpson (2007) Major 20th century changes of carbonaceous aerosol components (EC, WinOC, DOC, HULIS, carboxylic acids, and cellulose) derived from Alpine ice cores, J. Geophys. Res., 112, D23S11, doi:10.1029/2006JD008080.

Lemire, K. R., D. T. Allen, G. A. Klouda, and C. W. Lewis (2002), Fine particulate matter source attribution for Southeast Texas using ${ }^{14} \mathrm{C} /{ }^{13} \mathrm{C}$ ratios, J. Geophys. Res., 107(D22), 4613, doi:10.1029/2002JD002339.
Levin, I., and B. Kromer (2004), The tropospheric ${ }^{14} \mathrm{CO}_{2}$ level in midlatitudes of the Northern Hemisphere (1959-2003), Radiocarbon, 46, $1261-1272$

Lewis, C. W., G. A. Klouda, and W. D. Ellenson (2004), Radiocarbon measurement of biogenic contribution to summertime PM2.5 ambient aerosol in Nashville, TN, Atmos. Environ., 38, 6053-6061.

Limbeck, A., M. Kulmala, and H. Puxbaum (2003), Secondary organic aerosol formation in the atmosphere via heterogeneous reaction of gaseous isoprene on acidic particles, Geophys. Res. Lett., 30(19), 1996, doi:10.1029/2003GL017738.

Liousse, C., J. E. Penner, C. Chuang, J. J. Walton, H. Eddleman, and H. Cachier (1996), A global three-dimensional model study of carbonaceous aerosols, J. Geophys. Res., 101(D14), 19,411-19,432.

Martins, J. V., P. Artaxo, C. Liousse, J. S. Reid, P. V. Hobbs, and Y. J. Kaufman (1998), Effects of black carbon content, particle size, and mixing on light absorption by aerosols from biomass burning in Brazil, J. Geophys. Res., 103(D24), 32,041-32,050.

Matthias-Maser, S., and R. Jaenicke (1994), Examination of atmospheric bioaerosol particles with radii $>0.2 \mu \mathrm{m}, J$. Aerosol Sci., 25, 1605-1613. Oros, D. R., and B. R. T. Simoneit (2001a), Identification and emission factors of molecular tracers in organic aerosols from biomass burning Part I. Temperate climate conifers, Appl. Geochem., 16, 1513-1544.

Oros, D. R., and B. R. T. Simoneit (2001b), Identification and emission factors of molecular tracers in organic aerosols from biomass burning. Part II. Deciduous trees, Appl. Geochem., 16, 1545-1565.

Penner, J. E., et al. (2001), Aerosols, their Direct and Indirect Effects, in Climate Change 2001: The Scientific Basis-Contribution of Working Group I to the Third Assessment Report of the Intergovernmental Panel on Climate Change, edited by J. T. Houghton et al., pp. 289-348, Cambridge Univ. Press, New York.

Pio, C. A., et al. (2007), Climatology of aerosol composition (organic versus inorganic) at non-urban areas on a West-East transect across Europe, J. Geophys. Res., doi:10.1029/2006JD008038, in press.

Puxbaum, H., and M. Tenze-Kunit (2003), Size distribution and seasonal variation of atmospheric cellulose, Atmos. Environ., 37(26), 3693-3699.

Puxbaum, H., A. Caseiro, A. Sánchez-Ochoa, A. Kasper-Giebl, M. Claeys, A. Gelencsér, S. Preunkert, M. Legrand, and C. A. Pio (2007), Levoglucosan levels at background sites in Europe for assessing the impact of biomass combustion on the European aerosol background, J. Geophys. Res., doi:10.1029/2006JD008114, in press.

Schell, B., I. J. Ackermann, H. Hass, F. S. Binkowski, and A. Ebel (2001) Modeling the formation of secondary organic aerosol within a comprehensive air quality model system, J. Geophys. Res., 106(D22), 28,27528,293

Schmid, H., et al. (2001), Results of the "carbon conference" international aerosol carbon round robin test stage I, Atmos. Environ., 35(12), $2111-$ 2121

Schmidl, C. (2005), PM10-Quellenprofile von Holzrauchemissionen aus Kleinfeuerungen, diplomarbeit, Inst. für Chem. Technol. und Anal., Tech. Univ. Wien, Vienna.

Simoneit, B. R. T., J. J. Schauer, C. G. Nolte, D. R. Oros, V. O. Elias, M. P. Fraser, W. F. Rogge, and G. R. Cass (1999), Levoglucosan, a tracer for cellulose in biomass burning and atmospheric particles, Atmos. Environ., 33(2), 173-182.

Simpson, D., A. Gelencsér, A. Caseiro, Z. Klimont, K. Kupiainen, M. Legrand, C. Pio, H. Puxbaum, V. Vestreng, and K. E. Yttri (2007), Modeling carbonaceous aerosol over Europe: Analysis of the CARBOSOL and EMEP EC/OC campaigns, J. Geophys. Res., 112, D23S14, doi:10.1029/2006JD008158.

Steier, P., R. Drosg, M. Fedi, W. Kutschera, M. Schock, D. Wagenbach, and E. M. Wild (2006), Radiocarbon determination of particulate organic carbon in non-temperated, Alpine glacier ice, Radiocarbon, 48, 69-82.

Szidat, S., et al. (2004), Radiocarbon $\left({ }^{14} \mathrm{C}\right)$-deduced biogenic and anthropogenic contributions to organic carbon (OC) of urban aerosols from Zürich, Switzerland, Atmos. Environ., 38, 4035-4044.

Tsigaridis, K., and M. Kanakidou (2003), Global modeling of secondary organic aerosol in the troposphere: A sensitivity analysis, Atmos. Chem. Phys., 3, 1849-1869.

Tsyro, S., D. Simpson, L. Tarrason, Z. Klimont, K. Kupiainen, C. Pio, and K. E. Yttri (2007), Modeling of elemental carbon over Europe, J. Geophys. Res., doi:10.1029/2006JD008164, in press.

Turpin, B. J., and J. J. Huntzicker (1991), Secondary formation of organic aerosol in the Los Angeles basin: A descriptive analysis of organic and elemental carbon concentrations, Atmos. Environ., Part A, 25(2), 207215

Volkamer, R., J. L. Jimenez, F. San Martini, K. Dzepina, Q. Zhang, D. Salcedo, L. T. Molina, D. R. Worsnop, and M. J. Molina (2006), Secondary organic aerosol formation from anthropogenic air pollution: Rapid and higher than expected, Geophys. Res. Lett., 33, L17811, doi:10.1029/2006GL026899. 
Watson, J. G., J. C. Chow, and J. E. Houck (2001), PM2.5 chemical source profiles for vehicle exhaust, vegetative burning, geological material, and coal burning in northwestern Colorado during 1995, Chemosphere, 43, $1141-1151$

A. Caseiro and C. Pio, Departamento de Ambiente e Ordenamento, Universidade de Aveiro, 3810-193, Aveiro, Portugal.

A. Gelencsér, Air Chemistry Group of the Hungarian Academy of Sciences, Department of Earth and Environmental Sciences, University of Pannonia, P.O. Box 158, H-8201, Veszprém, Hungary. (gelencs@almos. uni-pannon.hu)
A. Kasper-Giebl, H. Puxbaum, and A. Sánchez-Ochoa, Institute for Chemical Technologies and Analytics, Vienna University of Technology, A-1040 Vienna, Austria.

M. Legrand, Laboratoire de Glaciologie et Géophysique de l'Environnement, Centre National de la Recherche Scientifique, F-38402 Saint Martin d'Heres, France.

B. May, Insitute für Umweltphysik, University of Heidelberg, D-69120 Heidelberg, Germany.

D. Simpson, Cooperative Programme for Monitoring and Evaluation of the Long-Range Transmission of Air Pollutants in Europe, Meteorological Synthesizing Centre-West, Norwegian Meteorological Institute, N-0313 Oslo, Norway. 